\title{
The influence of small-scale flow and chemical cues on the settlement of two congeneric barnacle species
}

\author{
John R. Wright*, Anthony J. Boxshall** \\ Department of Zoology, University of Melbourne, Parkville, Victoria 3052, Australia
}

\begin{abstract}
We report the results of 2 types of field experiment done to examine the influence of the interaction between small-scale flow disruptions and chemical cues associated with conspecific individuals on the settlement of larvae of 2 congeneric barnacle species, Elminius modestus and $E$. covertus. One series of experiments (ridge experiments) examined the effects of the chemical component of barnacle presence and flow disruptions at the scale of settlement plates $(<10 \mathrm{~cm})$. Cyprids could contact surfaces containing chemical cues from conspecific adults on either ridged or flat plates. Settlement was greatest on plates with cues but was not affected by flow disruptions. The other experiment (mimic experiment) used settlement plates with either live barnacles or casts of adult barnacles attached, as well as flat control plates, to test the influence of conspecific presence and flow disruption at the scale of individual barnacles $(<1 \mathrm{~cm})$ on the settlement of cyprids. Settlement was affected by both live barnacles and barnacle mimics, indicating that a combination of flow and conspecific-derived cues influence settlement. Hence, the importance of flow disruption to the settlement of cyprids is dependent on the scale of the disruption. The survival of barnacles for up to 2 mo after settlement was also followed in the ridge experiments. The settlement patterns larvae showed early in these experiments were not evident after periods of heavy recruitment; we discuss possible causes.
\end{abstract}

KEY WORDS: Settlement - Recruitment - Larval behaviour - Chemical cues - Hydrodynamics - Barnacles. Elminius modestus Elminius covertus

\section{INTRODUCTION}

Settlement and recruitment are important processes structuring adult barnacle populations (recent examples: Raimondi 1988a, Sutherland 1990, Minchinton \& Scheibling 1993) and both processes can vary across spatial and temporal scales (Le Tourneux \& Bourget 1988, Raimondi 1990, Jarrett 1997). Factors affecting settlement and supply are various and complex (see Minchinton \& Scheibling 1993, Rodriguez et al. 1993 for a more detailed review of the factors influencing larval settlement). Near the settlement surface, benthic

- Present addresses: Conservation Division, Parks Victoria Private Bag 8, Kew, Victoria 3101, Australia

-Addressee for correspondence. Department of Biology,

University of California, Santa Cruz, California 95064, USA.

E-mail: boxshall@biology.ucsc.edu predators (by filtration: Mileikovsky 1974, Morgan 1995), larval behaviours (to surface contour: Crisp \& Barnes 1954, Lemire \& Bourget 1996; to conspecifics: Knight-Jones 1953, Crisp \& Meadows 1963, Larman \& Gabbott 1975, Raimondi 1988b; to biofilms: Maki et al. 1989) and aspects of small-scale hydrodynamics (Walton Smith 1946, Crisp 1955, Wethey 1986, Mullineaux \& Butman 1991) influence the settlement of barnacle larvae. On the surface, the settlement patterns of barnacles are altered by the presence of adsorbed chemical cues originating from conspecifics (Rittschof et al. 1984, Raimondi 1988b, Jarrett 1997) that are extremely difficult to deactivate on some surfaces (Gabbott \& Larman 1987).

The role of chemistry, hydrodynamics and larval behaviour as influences on the settlement of invertebrate larvae has been discussed for many years (e.g. Crisp 1955, Meadows \& Campbell 1972, Butman 1987. 
Mullineaux \& Garland 1993). Since the seminal review by Butman (1987) many workers have done laboratorybased experiments, with various taxa, to test the interaction between hydrodynamics and behavioural cues on the settlement of larvae (Mullineaux \& Butman 1991, Grassle et al. 1992, Pawlik \& Butman 1993, Snelgrove et al. 1993, Turner et al. 1994). Despite much work on this interaction in the laboratory, until recently there has been little work in the field testing this interaction (see Harvey et al. 1995, Lemire \& Bourget 1996 , Miron et al. 1996). It is important to test for an interaction in the field because the complex nature of conditions in the field may prevent behaviours seen in the laboratory from being expressed. In a simple example, a response to a chemical cue in static laboratory conditions may be quite different in field flows.

The influence of both hydrodynamics and cue choice on settling larvae is scale dependent (e.g. Le Tourneux \& Bourget 1988, Harvey et al. 1995, Hills \& Thomason 1996). Many studies of larval settlement choices test the effect of either flow or cues (e.g. Rittschof et al. 1984, Wethey 1986, Mullineaux \& Butman 1991, Walters 1992a), but rarely both at a scale near that of larvae and in a field situation.

Settlement choices may influence recruitment patterns but post-settlement processes may influence barnacle population dynamics more than larval processes (e.g. Connell 1961a, Bertness 1989). Gaines \& Roughgarden (1985) commented that the individual behaviours of cyprids may be masked when supply of cyprids is large. Minchinton \& Scheibling (1993) found the settlement preferences of the barnacle Semibalanus balanoides on a rocky shore in Nova Scotia, Canada, were masked when larval supply was saturating. To our knowledge, no study has followed through to recruitment any larvae that have made specific choices in response to cues experimentally manipulated at the scale of the adult barnacle. From an ecological perspective, it is important to know if the settlement patterns persist past initial larval choice, especially as the settlement patterns of initial settlers may also affect either the choices of subsequent settlers or the survival of existing recruits.

The experiments we describe were designed to test the relative influence of small-scale flow disruptions and the larval response to chemical cues (sensu Butman 1987) on the settlement and recruitment of 2 congeneric barnacles, Elminius modestus and E. covertus, under field conditions. We did experiments at 2 scales that assessed larval responses to disruptions of boundary flow and to cues from conspecifics. We were not attempting to quantify the boundary flow conditions (sensu Mullineaux \& Butman 1991, Mullineaux \& Garland 1993); however, we altered the settlement surfaces at 2 scales to provide boundary flow disruptions similar to those used by other authors (e.g. Wethey 1986, Mullineaux \& Butman 1991, Walters 1992b, Mullineaux \& Garland 1993, Lemire \& Bourget 1996, Miron et al. 1996). By not quantifying the boundary conditions, the design we used did not allow us to comment on the exact mechanism of flow disruption that influenced the larvae (see Mullineaux \& Garland 1993 for a full discussion of this issue).

One experiment considered flow disruption at the scale of adult barnacles $(<1 \mathrm{~cm})$, and compared settlement around live barnacles, mimic barnacles and on flat surfaces. The second set of experiments examined a flow disruption at a slightly larger scale $(<10 \mathrm{~cm})$ and compared the importance of cues on ridged and flat areas on settlement plates. We predicted that both the conspecific cue and the hydrodynamics produced by the flow disruptions would influence the settlement patterns. During some experiments there were periods of high larval settlement. We followed recruitment to see whether the patterns of individual behaviour at settlement were masked by these high-settlement events.

\section{METHODS}

Ridge experiments. To test the interaction of barnacles to settlement cues and flow disruption at a scale of around $10 \mathrm{~cm}$, the settlement and recruitment of 2 congeneric barnacles, Elminius modestus and E. covertus, were followed on settlement plates either with or without small-scale flow disruptions, and in the presence or absence of a settlement cue. Ridges were used as roughness elements to alter the boundary flow over the settlement plates and would provide a second disruption to the formation of an equilibrium boundary layer close to the first disruption at the plate edge. As such, the ridges should have caused increased boundary turbulence compared to similar regions on plates without ridges. However, potentially increasing larval contact to the ridges may not necessarily increase larval attachment or settlement (Denny 1988, Gross et al. 1992, Mullineaux \& Garland 1993, Vogel 1994, Boxshall 1996). All plates used in these experiments were made of grey PVC and attached to backing surfaces with stainless steel bolts.

Rather than extracting cues and painting them on the settlement surfaces (e.g. Rittschof et al. 1984), we used cues remaining on the surface after removing barnacle recruits. Barnacles of the genus Elminius do not have a basal plate that remains after removing the adult test, rather they have a basal membrane which leaves some visible evidence of previous barnacle attachment, but no calcareous structure. The remains of the basal membrane act as a cue to cyprids and are 
active for up to months and even years under some conditions (Gabbott \& Larman 1987). The surfaces containing adsorbed cues came from plates used in earlier recruitment experiments with heavy colonisation by barnacles. These recruitment events completely covered the plates with barnacles, which were left to grow for at least $4 \mathrm{mo}$. The plates were left to dry for at least 3 mo before we removed the adult tests, exposing the cues on the surface.

As a measure of settlement, every attached, live individual and any evidence of metamorphosis was recorded. Due to the short census periods (see Figs. 1, 2 \& 3 for exact census periods), many newly settled individuals retaining cyprid characteristics were observed. Removal of these individuals left a characteristic imprint on the surface that remained for at least $2 \mathrm{~d}$ (authors' pers. obs). Although rare, these imprints were counted as evidence of settlement. It is possible they are cyprid cement or antennular secretions (Clare et al. 1994). In the present set of experiments, settlers were not removed or damaged in any way after census.

For analyses, all data were transformed to a $\log _{10}$ scale to improve normality and stabilise variance (Sokal \& Rohlf 1981). Analyses were done on the number of barnacles settled or recruited at 2 census times (at Days 8 and 24) in Expt 1 and 4 census times (after 7 tides, $10 \mathrm{~d}, 25 \mathrm{~d}$ and $65 \mathrm{~d}$ ) in Expt 2.

Plates used in these experiments were $100 \times 50 \mathrm{~mm}$ and belonged to 1 of 4 treatments: (1) Flat plates without a cue (abbreviated to FNC). (2) Ridged plates without a cue (RNC). These plates had 2 ridges of grey PVC $(100 \times 6 \times 6 \mathrm{~mm})$ added as flow disruptions running vertically down the plates, $10 \mathrm{~mm}$ from either side. (3) Flat plates with a cue (FC). (4) Ridged plates with a cue (RC). For FC and RC, each whole plate and/or ridge was cut from plates with settlement cues. All new plates were sanded lightly and rinsed in seawater before use.

Sixteen plates were arranged on either a backing plate and covered by at least $2 \mathrm{~m}$ of water at all times (Breakwater Pier) or intertidally on 2 wooden racks (Rhyll) in a Latin square design. The same 2-dimensional area was available on both $\mathrm{FC}$ and $\mathrm{RC}$ plates. Only individuals on ridges or the corresponding areas on the flat plates were counted.

The first experiment was done at Breakwater Pier, Williamstown in Victoria, Australia (described in Todd \& Keough 1994), in December 1994. Two species dominate the barnacle assemblage at Breakwater Pier: Balanus variegatus and Elminius modestus. B. variegatus rarely settled during this experiment but was easily distinguished from $E$. modestus individuals, which have 4 compartmental plates (Buckeridge 1983) compared with the 6 compartmental plates of $B$. variegatus. Many other taxa of sessile marine invertebrates recruit subtidally at Breakwater Pier (Todd \& Keough 1994, Keough \& Raimondi 1995, Boxshall 1996). At the site, flows are low to moderate (peak flow $15 \mathrm{~cm} \mathrm{~s}^{-1}$ during a rising tide and $13 \mathrm{~cm} \mathrm{~s}^{-1}$ during a falling tide; Scott Chidgey, Consulting Environmental Engineers, pers. comm.).

Expt 2 was done at Rhyll Pier, Phillip Island, Victoria, Australia, in December 1994 and January 1995. Details of this site are provided by Wright (1996). The barnacle Elminius covertus occurs intertidally where it forms a virtual monoculture. The tidal range at Rhyll $(\sim 3 \mathrm{~m})$ is greater than at Williamstown $(\sim 0.8 \mathrm{~m})$ and moderate to high tidal flows occur at Rhyll Pier. At a nearby subtidal station $10 \%$ of tides have a maximum velocity greater than $46 \mathrm{~cm} \mathrm{~s}^{-1}$ and $50 \%$ are greater than $35 \mathrm{~cm}$ $\mathrm{s}^{-1}$ (Western Port Bay Environmental Study 1975).

For Expt 1, the plates were placed in a trough of seawater and a hand-held dissecting microscope (20x magnification) was used to observe settlers/recruits of Elminius modestus at each census. Expt 2 was sampled at low tide by examining plates with a hand-held dissecting microscope (20× magnification) and counting settlers/recruits. The mean settlement and recruitment of $E$. modestus or E. covertus per plate was analysed with a 2-way ANOVA ('cue': fixed, 2 levels-C, NC; 'flow': fixed, 2 levels $-R, F$ ).

Mimic experiment. To examine how the presence of conspecific individuals and flow disruption caused by the surface irregularities associated with conspecific individuals affects settlement, we monitored settlement of Elminius covertus on 2 types of plate in early 1994. The first type of plate we called 'live'. Early in December 1993, grey PVC settlement plates $(100 \times$ $50 \mathrm{~mm}$ ) were attached to wooden racks affixed to Rhyll pier. Individuals of $E$. covertus were allowed to settle and grow on these plates for several weeks. The plates were cut in half to make $50 \times 50 \mathrm{~mm}$ plates. The density of individuals on these smaller plates was adjusted so each plate fitted into 1 of 3 treatments that represented natural levels of barnacle cover on the pier: (1) Clustered (C). Barnacles on these plates were in clusters of 3 to 6 individuals. About 4 to 6 such clusters were present on each of these plates. (2) Uncrowded (U). These plates had about 10 individuals on them. Each individual was surrounded by free space on all sides. (3) No barnacles (N). These were plates from which all barnacles had been removed. Due to a lack of settlement on some plates, and the requirement for $\mathrm{C}$ and $\mathrm{U}$ plates to have barnacles present, some of the plates allocated to the no barnacle treatment had no barnacles present initially. Consequently, we cannot be sure of the level of cue on these live-N plates.

The second type of plate we called 'mimic'. These plates were used to examine the effect on settlement of 
flow changes due to the physical presence of adult barnacles. These plates were made by taking casts of areas of the pier pilings where barnacles were in densities and arrangements similar to those described for the live barnacle plates with barnacles present. Moulds were made using Ivopal cream alginate (Ivoclar Pty Ltd, Noble Park, Victoria, Australia). Plates were cast from these moulds using K\&H Kahfil Plastic Putty (K\&H Pty Ltd, Dandenong, Victoria, Australia) and coloured with grey pigment so the plates were similar in colour to the PVC used for the Live barnacle plates. Flat plates, similar to the 'no barnacle' plates, were also made from the plastic putty. To remove any toxic residues from the plastic putty, all plates made from the putty were soaked in fresh water, which was regularly changed throughout a 2 wk period. This technique seemed to be effective as the flat control plates received the same settlement whether they were made from PVC or plastic putty (see 'Results'). In summary, there was a total of 6 types of plates: 3 types of live barnacle plates and 3 types of mimic barnacle plates.

The plates were set out in the field on January 9 , 1994. One of each type of plate was attached at the upper vertical limit and within the core of the vertical range of Elminius covertus on both the inward and out- ward faces of 5 pilings on each side of the pier (a total of 240 plates; i.e. 40 replicates of each treatment). The position of each plate within the possible attachment area was determined at random. Plates were attached to the pier with a 2-part epoxy glue.

Sampling of the plates began on January 11, 1994 , and was done on each of the following 6 low tides except the third low tide, when bad weather prevented sampling. All individuals that had settled since January 9 were removed from each plate with a needle at the start of monitoring. During the experiments, settlers were not removed after census. The plates were sampled by overlaying with a clear plastic sheet and marking the position of each new individual on the sheet.

Settlement was analysed with a 2-way factorial ANOVA (plate type [fixed, 2 levels] and density [fixed, 3 levels] were grouping variables; total settlement over the 6 tides was the dependent variable. For each plate type, settlement was also analysed using a 1-way ANOVA (density: fixed, 3 levels). Planned comparisons were done to test for differences in settlement between presence of barnacles (or mimics) and absence of barnacles (or mimics) to examine the effect of the physical presence of a barnacle-sized structure on settlement. Planned comparisons were also done between uncrowded

Table 1. Results of ANOVA for all experiments. $p<0.0005$ where $p=0.000$. Significant $p$-values are given in bold

\begin{tabular}{|c|c|c|c|c|c|}
\hline Expt & Source of variation & df & MS & $F$ & $\mathrm{p}$ \\
\hline Ridge Expt 1 & Cue & 1 & 11.134 & 169.399 & 0.000 \\
\hline \multirow{3}{*}{$\begin{array}{l}\text { Settlement after } 8 \mathrm{~d} \\
(8 \mathrm{~d})\end{array}$} & Flow & 1 & 0.225 & 3.417 & 0.092 \\
\hline & Cue $\times$ Flow & 1 & 0.045 & 0.678 & 0.428 \\
\hline & Error & 11 & 0.066 & & \\
\hline Ridge Expt 1 & Cue & 1 & 0.003 & 0.270 & 0.614 \\
\hline \multirow{3}{*}{$\begin{array}{l}\text { Recruitment after } 24 \mathrm{~d} \\
(24 \mathrm{~d})\end{array}$} & Flow & 1 & 0.002 & 0.117 & 0.738 \\
\hline & Cue $\times$ Flow & 1 & 0.003 & 0.252 & 0.626 \\
\hline & Error & 11 & 0.013 & & \\
\hline Ridge Expt 2 & Cue & 1 & 2.611 & 12.361 & 0.004 \\
\hline \multirow{3}{*}{$\begin{array}{l}\text { Settlement after } 3.5 \mathrm{~d} \\
\text { ( } 7 \text { tides) }\end{array}$} & Flow & 1 & 0.096 & 0.457 & 0.512 \\
\hline & Cue $\times$ Flow & 1 & 0.012 & 0.059 & 0.812 \\
\hline & Error & 12 & 0.211 & & \\
\hline Ridge Expt 2 & Cue & 1 & 2.987 & 13.450 & 0.003 \\
\hline \multirow{3}{*}{$\begin{array}{l}\text { Recruitment after } 10 \mathrm{~d} \\
(10 \mathrm{~d})\end{array}$} & Flow & 1 & 0.115 & 0.518 & 0.485 \\
\hline & Cue $\times$ Flow & 1 & 0.115 & 0.518 & 0.485 \\
\hline & Error & 12 & 0.222 & & \\
\hline Ridge Expt 2 & Cue & 1 & 0.378 & 3.802 & 0.080 \\
\hline \multirow{3}{*}{$\begin{array}{l}\text { Recruitment after } 25 \mathrm{~d} \\
(25 \mathrm{~d})\end{array}$} & Flow & 1 & 0.003 & 0.032 & 0.861 \\
\hline & Cue $\times$ Flow & 1 & 0.023 & 0.230 & 0.642 \\
\hline & Error & 10 & 0.099 & & \\
\hline Ridge Expt 2 & Cue & 1 & 0.026 & 1.421 & 0.261 \\
\hline \multirow{3}{*}{$\begin{array}{l}\text { Recruitment after } 65 \mathrm{~d} \\
(65 \mathrm{~d})\end{array}$} & Flow & 1 & 0.003 & 0.162 & 0.696 \\
\hline & Cue $\times$ Flow & 1 & 0.016 & 0.876 & 0.371 \\
\hline & Error & 10 & 0.018 & & \\
\hline \multirow[t]{4}{*}{ Mimic experiment } & Plate Type & 1 & 181.492 & 8.939 & 0.003 \\
\hline & Density & 2 & 368.600 & 18.183 & 0.000 \\
\hline & Plate Type $\times$ Density & 2 & 59.677 & 2.944 & 0.055 \\
\hline & Error & 216 & 20.272 & & \\
\hline
\end{tabular}


and clustered treatments to examine the effects of the arrangement of barnacle-sized structures on settlement.

\section{RESULTS}

\section{Ridge Expt 1 (EIminius modestus)}

After 8 d, Elminius modestus larvae had settled preferentially to a conspecific cue regardless of the flow disruption. However, by the end of the experiment $16 \mathrm{~d}$ later) there was no difference in the total recruitment due to either of the treatments (Table 1, Fig. 1). A large recruitment event occurred between Days 9 and 24 .

\section{Ridge Expt 2 (Elminius covertus)}

After 7 full tidal cycles, Elminius covertus larvae also settled preferentially to a conspecific cue regardless of the flow disruption (Table 1, Fig. 2). After a further $6 \mathrm{~d}$, the larvae still preferentially recruited to a cue regardless of the flow. However, after a further $15 \mathrm{~d}$ (Day 25), there was no difference in the total recruitment due to either treatment (Table 1, Fig. 3). After a further 55 d, there was no difference in the total recruitment due to either treatment (Table 1, Fig. 3). There were large recruitment events between Days 1025 and again between Days 25 and 65.

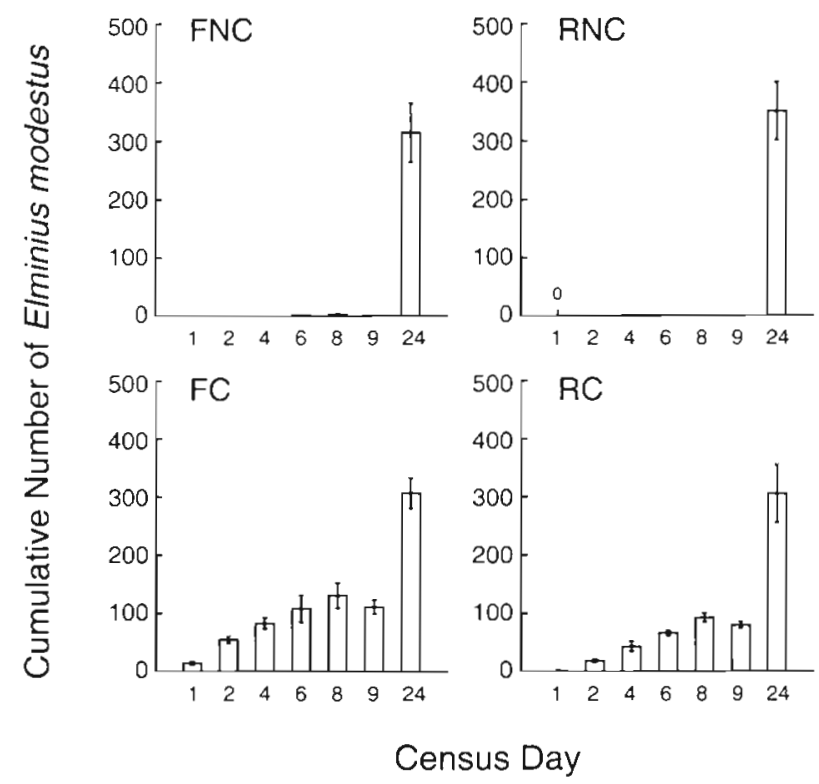

Fig. 1. Settlement (Day 8) and recruitment (Day 24) of Elminius modestus onto $50 \times 100 \mathrm{~mm}$ settlement plates in ridge Expt 1 (Williamstown). Data are means \pm 1 SE of 4 replicate plates, $\mathrm{R}=$ ridged, $\mathrm{F}=$ flat, $\mathrm{C}=$ cue present, $\mathrm{NC}=$ cue absent. A. ' 0 ' indicates no settlement at that census date
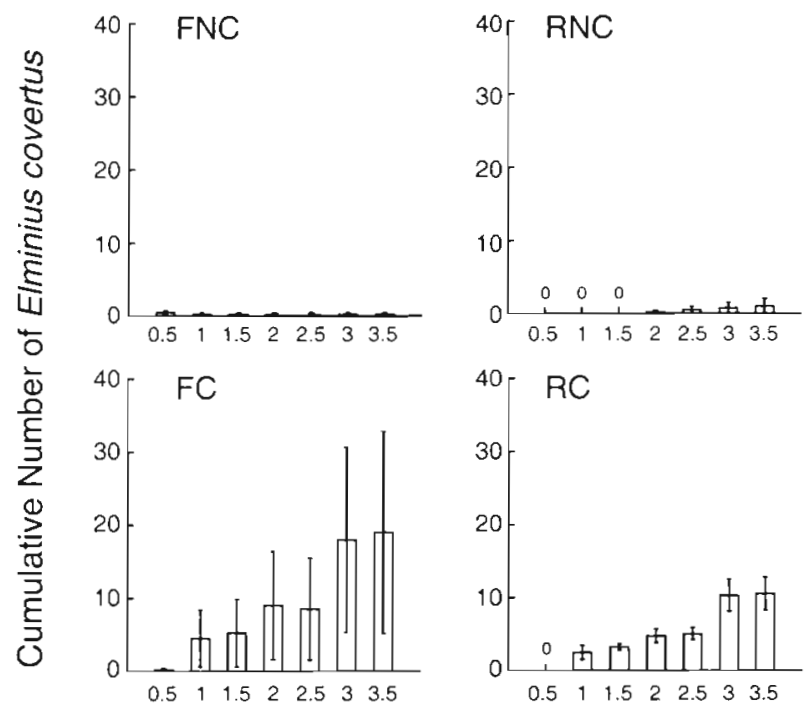

Census Day

Fig. 2. Settlement of Elminius covertus onto $50 \times 100 \mathrm{~mm}$ settlement plates in ridge Expt 2 (Rhyll). Data are means $\pm 1 \mathrm{SE}$ of 4 replicate plates, $\mathrm{R}=$ ridged, $\mathrm{F}=$ flat, $\mathrm{C}=$ cue present, $\mathrm{NC}$ = cue absent. $\mathrm{A}$ ' $O$ ' indicates no settlement at that census date

\section{Mimic experiment (EIminius covertus)}

The presence of conspecifics had an effect on the settlement of Elminius covertus cyprids (Table 1). Settlement on plates with live barnacles was greater than that on plates with barnacle mimics (Fig. 4). There was also an effect of density on settlement of $E$. covertus (Table 1). Ranking of density treatments with respect to settlement intensity was the same for live and mimic barnacle plates (Fig. 4). For both types of plates, settlement was highest on $\mathrm{C}$ plates and lowest on $\mathrm{N}$ plates.

On live plates there was no significant difference between $\mathrm{C}$ and $\mathrm{U}$ treatments (planned comparison, $\mathrm{p}=$ 0.133), but settlement on plates with barnacles present was higher than on plates without barnacles present (planned comparison, $\mathrm{p}=0.000$ ).

On mimic plates, again there was no significant difference between $\mathrm{C}$ and $\mathrm{U}$ treatments (planned comparison, $p=0.366$ ), but there was higher settlement on plates with barnacle mimics than on plates without mimics (planned comparison, $\mathrm{p}=0.008$ ).

\section{DISCUSSION}

The settlement of both species of barnacle considered in this study was affected by chemical cues associated with conspecific individuals. In the mimic experiment, settlement was greater on plates with live barnacles than on plates without live barnacles, and 


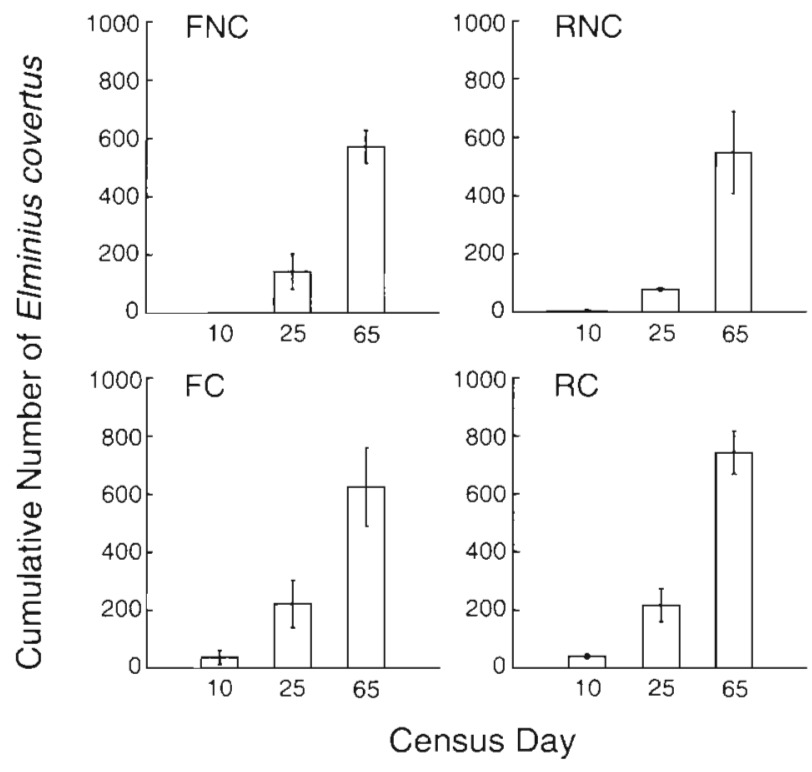

Fig. 3. Recruitment of Elminius covertus onto $50 \times 100 \mathrm{~mm}$ settlement plates in ridge Expt 2 (Rhyll). Data are means $\pm 1 \mathrm{SE}$ of 4 replicate plates; $\mathrm{R}=$ ridged, $\mathrm{F}=$ flat, $\mathrm{C}=$ cue present, $\mathrm{NC}=$ cue absent

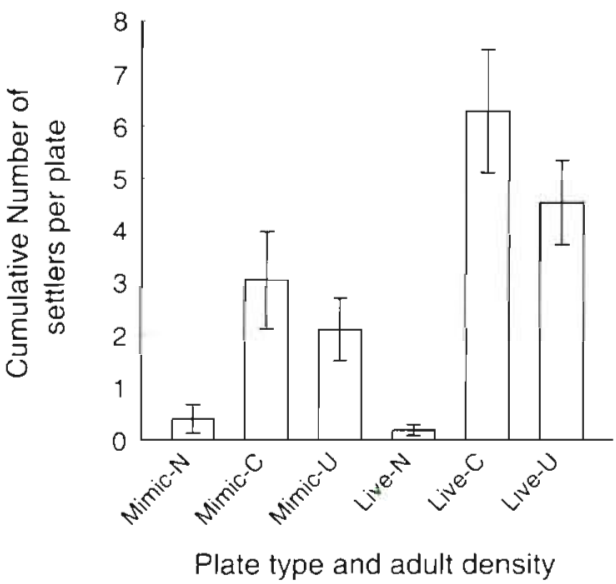

Fig. 4. Total settlement of Elminius covertus onto $50 \times 50 \mathrm{~mm}$ settlement plates in the mimic experiment. Data are means \pm $1 \mathrm{SE}$ of 4.0 replicate plates; $\mathrm{N}=$ no barnacles, $\mathrm{U}=$ uncrowded, $\mathrm{C}=$ clustered

the ridge experiments show that chemical cues associated with conspecifics, rather than the physical presence of conspecifics, are sufficient to induce settlement (see also Miron et al. 1996). This result was consistent across 2 congeneric species of barnacles at 2 field sites and is consistent with the general findings of other studies of barnacle settlement in field situations (e.g. Raimondi 1988a,b, Minchinton \& Scheibling 1993).

As predicted, settlement of cyprids was also influenced by disruptions to the flow. These experiments allowed us to test this influence at 2 different scales and the effect of flow on settling larvae depended on the scale of disruption. In the mimic experiment, settlement of Elminius covertus was greater on plates with barnacles or barnacle mimics than it was on flat plates, which suggests that, in addition to the chemical cues associated with barnacles, the physical presence of barnacles also influenced settlement patterns.

Mullineaux \& Butman (1991) provided evidence that initial contact of the substratum in a flume by cyprids of Balanus amphitrite was due to hydrodynamic or passive processes (for examples with other taxa, see Keen 1987. Pawlik \& Butman 1993). In our mimic experiment a similar process could have been operating. The boundary flow over plates that had structural complexity (either live or mimic barnacles) would be different to that over flat plates. The barnacle shape on the surfaces will result in a more turbulent boundary flow (Denny 1988, Mullineaux \& Garland 1993) than on flat plates. This will increase larval contacts on the rough surfaces compared with flat plates (Yager et al. 1993, Gregoire et al. 1996). If settlement is directly related to larval contacts, then we would predict increased settlement on the rough plates. Although this mechanism alone could explain the increased settlement onto the rough plates, there are alternatives (Mullineaux \& Garland 1993).

Larvae are known to explore the substratum following initial contact (e.g. LeTourneux \& Bourget 1988, Walters 1992), and during this exploration may respond to an aspect of flow (Crisp 1955, Mullineaux \& Butman 1991) or even be unable to remain due to flow conditions (shear region: Neal \& Yule 1994). Mullineaux \& Garland (1993) showed that specific flow conditions may act as a cue to settlement in the field. Walters (1992) showed that settlement patterns of Balanus amphitrite around the bases of bumps on Lego blocks could not be explained by initial contact determined by flow, differential mortality or passive erosion by flow. She suggested that some aspect of post-contact behaviour at the small scale $(\mathrm{mm}$ to $\mathrm{cm}$ ) was the most likely explanation of such settlement patterns. Crisp \& Barnes (1954) discussed the possible rugophilic, or tactile, nature of a barnacle larval settlement cue. The changes to local topography in the mimic experiment may offer such a tactile cue.

Interestingly, in the mimic experiment, we noted that the majority of settlers attached on or at the edge of adult individuals or mimics (authors' pers, obs.). Consequently, in the mimic experiment, greater settlement on rougher plates may be due to larvae responding to some aspect of flow near the bases of barnacles and mimics, or it may be due to a tactile cue.

Miron et al. (1996) found that settlement of Balanus crenatus was affected by both hydrodynamics and the 
presence of conspecifics; however, unlike our results, they found settlement did not occur in the absence of conspecifics. Based on the results of field and flume experiments, they concluded that settlement behavjour of larvae was influenced by small-scale hydrodynamics, but chemical cues are most important in the selection of settlement sites after initial contact. However, LeTourneux \& Bourget (1988) found that at very small scales (the size of the antennular disc), surface heterogeneity was most important to larval site selection. Although we found greater settlement on plates with live barnacles than with mimics, due to the lack of chemical cues on some flat plates in the mimic experiment (see 'Methods'), we are unable to rank the influence of hydrodynamic processes and chemical cues on settlement.

In our mimic experiment, the plates with live barnacles presented cyprids with chemical cues and flow disruption, whereas the plates with mimics provided only flow disruption. That there were more settlers on live barnacle plates than on plates with mimics suggests that flow and chemical cues associated with conspecifics interact. Another alternative, albeit unlikely, is that the feeding action of the live adults generated small flow patterns that enhanced barnacle settlement. The barnacle settlement observed in both experiments was consistent with recent work suggesting that individual larval cues do not operate in isolation from each other or from cues associated with flow (Mullineaux \& Garland 1993, Dineen \& Hines 1994, Neal \& Yule 1994, Boxshall 1996). We have studied 2 of the suite of cues that can influence settlement. Although not considered here, the cues we examined may also interact with other cues known to affect the settlement of marine invertebrate larvae (e.g. biofilms: Todd \& Keough 1994, Wieczorek \& Todd 1997; light: Young 1995).

The experiments were designed to offer cyprids flow disruptions at 2 scales: one at the level of a plate (the ridges) and the second at the level of attachment (barnacle-sized structure). The result predicted for the ridge experiments was that any preference of larvae for conspecific cues would be affected by the ridges used to disrupt flow. However, the ridges did not affect settlement. This result was surprising as the ridges should alter boundary flow, given their size as a roughness element (Nowell \& Jumars 1987, Vogel 1994) and the size of flow disruptions shown to affect the settlement of other taxa in other field trials (Walters 1992a, Mullineaux \& Garland 1993, Boxshall 1996, Lemire \& Bourget 1996). That surface heterogeneity, and consequent flow disruption, affected settlement in the mimic experiment but not in the ridge experiments is most likely an issue of scale. The mimics probably offered the cyprids a hydrodynamic disruption at a scale more meaningful to their settlement than the ridges. The ridges did not alter settlement patterns and we cannot differentiate clearly between a mechanism based on larval behaviour and the simple fact that the disruption may not have been at a scale applicable to settling cyprids.

It has been shown theoretically that much settlement in the field may occur at low to zero flow (e.g. Gross et al. 1992, Eckman et al. 1994). If this is the case, the mechanism of settlement on the mimic plates may be due to larval retention in eddies around barnacle mimics (sensu Wethey 1986). If increased settlement did occur in an area of low to zero flow in this experiment, it did not occur in a time of low to zero flow. In a separate study Wright (1996) sampled E. covertus cyprid distribution at Rhyll in the water column over two $24 \mathrm{~h}$ periods (i.e. 4 high and 4 low tides). Maximum cyprid abundance was always during a rising tide and abundance at slack water was relatively low. Hence the cyprids in the experiments at Rhyll (mimic and ridge Expt 2) were mostly encountering the surfaces during a time of movement in the free-stream flow.

The recruitment patterns in the second Ridge Experiment, counted $6 \mathrm{~d}$ after settlement, showed a pattern that could be explained by a strong preference for a cue. However, when these same plates were monitored 15 d (ridge Expt 1) or 15 and 55 d (ridge Expt 2) after initial settlement was counted, there were no differences between the treatments. This is a similar result to that reported by Minchinton \& Scheibling (1993) for Semibalanus balanoides in Canada after real and simulated ice scour events.

In the ridge experiments, Elminius modestus and $E$. covertus showed a general pattern of settling very specifically when space (in this case surface area) was not limited. In a pilot study (authors' unpubl. data) during a time of light settlement, larval preference for a cue remained over time. However, heavy settlement during the ridge experiments resulted in complete coverage of all space (densities up to 30 barnacles $\mathrm{cm}^{-2}$ ). It would be interesting to know whether the barnacles that settled earlier actually gained any advantage from their behaviour (sensu Walters \& Wethey 1991, 1996, Walters 1992b) or if the later settlers had delayed their metamorphosis and become less selective (Jarrett 1997). Perhaps the early settlers grew faster or survived longer (e.g. Connell 1961b, Raimondi 1990), both of which may have enhanced reproductive output. Further work is required to answer these questions.

There are a number of implications of the fact that settlement choices of the early barnacles were masked by later recruitment events. At the scale of this experiment, settlement preferences may not be ecologically relevant in an area where larval supply varies in time, or is always high. Although interesting, the larval choice did not appear to control recruitment on the 
ridge experiments at either site. Other authors (e.g. Gaines \& Roughgarden 1985, Bertness et al. 1992, Minchinton \& Scheibling 1993) have suggested that the masking of settlement preferences may be due to larvae being forced to settle in less preferred sites during periods of high larval supply. Alternatively, the settlement patterns observed may still be a result of larval choice. In all of our experiments we noted some cyprids would settle on plates without cues. As these individuals settle and grow they change the nature of the plates in 2 ways: first, they introduce a chemical cue and, second, they change the small-scale hydrodynamics over the plates. Furthermore, biofilms on the settlement surfaces will also change over time (Keough \& Raimondi 1995. Wieczorek \& Todd 1997) so will the number of larvae contacting and leaving a conspecific cue from antennular prints (Clare et al. 1994). These changes may increase the attractiveness of the plates to larvae, so over time the differences between treatments may disappear. Alternatively, different cohorts of cyprids may be delaying their metamorphosis at different rates over a settlement season (see Jarrett 1997 for a discussion of this behaviour in Semibalanus balanoides). We believe that further work is required to understand the role that the changing nature of surfaces and larval behaviours play in settlement dynamics.

Acknowledgements. We thank Mick Keough, Alice King, Pete Raimondi and 3 anonymous reviewers for useful comments on this manuscript. We also thank Mick Keough for his support and advice during this study. Financial assistance for A.J.B. came, in part, from the Joyce W Vickery Fund (Linnean Soc. of NSW) and the Royal Society of Victoria. A.J.B. would like to thank Sonya Mulholland. We dedicate this paper to the memory of Ewen McGilp who died, far too young, in 1996.

\section{LITERATURE CITED}

Bertness MD (1989) Intraspecific competition and facilitation in a northern acorn barnacle population. Ecology 70 : $257-268$

Bertness MD, Gaines SD, Stephens EG, Yund PO (1992) Components of recruitment in populations of the acorn barnacle Semibalanus balanoides Linnaeus. J Exp Mar Biol Ecol 156:199-215

Boxshall AJ (1996) The interaction of small-scale hydrodynamics with the behaviour of settling marine invertebrate larvae. PhD thesis, University of Melbourne

Buckeridge JS (1983) The barnacle subfamily Elmininaetwo new subgenera and a new Miocene species from Victoria. J R Soc N Z 4:353-357

Butman CA (1987) Larval settlement of soft sediment invertebrates: the spatial scales of pattern explained by active habitat selection and the emerging role of hydrodynamical processes. Oceanogr Mar Biol Annu Rev 25:113-165

Clare AS, Freet RK, McClary MJ (1994) On the antennular secretion of the cyprid of Balanus amphitrite amphitrite, and its role as a settlement pheromone. J Mar Biol Assoc UK 74:243-250
Connell JH (1961a) The influence of interspecific competition and other factors on natural populations of the barnacle Chthamalus stellatus. Ecology 42:710-723

Connell JH (1961b) Effects of competition predation by Thais lapillus and other factors on natural populations of the barnacle Balanus balanoides. Ecol Monogr 31:61-104

Crisp DJ (1955) The behaviour of barnacle cyprids in relation to water movement over a surface. J Exp Biol 32:569-590

Crisp DJ, Barnes $\mathrm{H}$ (1954) The orientation and distribution of barnacles at settlement with particular reference to surface contour. J Anim Ecol 23:142-162

Crisp DJ, Meadows PS (1963) Adsorbed layers: the stimulus to settlement in barnacles. Proc R Soc Lond Ser B 158:364-387

Denny M (1988) Biology and the mechanics of the waveswept environment. 1st edn. Princeton University Press, Princeton

Dineen JF, Hines AH (1994) Larval settlement of the polyhaline barnacle Balanus eburneus (Gould): cue interactions and comparisons with two estuarine congeners. J Exp Mar Biol Ecol 179:223-234

Eckman JE, Werner FE, Gross TF (1994) Modelling some effects of behavior on larval settlement in a turbulent boundary layer. Deep-Sea Res Part II Top Stud Oceanogr 41:185-208

Gabbott PA, Larman VN (1987) The chemical basis of gregariousness in cirripedes: a review (1953-1984). In: Southward AJ (ed) Barnacle biology. AA Balkema, Rotterdam

Gaines SD, Roughgarden J (1985) Larval settlement rate: a leading determinant of structure in an ecological community of the marine intertidal zone. Proc Natl Acad Sci USA $82: 3703-3711$

Grassle JP, Butman CA, Mills SW (1992) Active habitat selection by Capitella sp. I. larvae: II. Multiple-choice experiments in still water and flume flows. J Mar Res 50:717-743

Grégoire Y, Bourget E, Verrette JL (1996) Deposition of mimics of planktonic invertebrate larvae on simple and complex substrata in flume flows. Mar Ecol Prog Ser 135: $89-100$

Gross TF, Werner FE, Eckman JE (1992) Numerical modelling of larval settlement in turbulent bottom boundary layers. J Mar Res 50:611-642

Harvey M, Bourget E, Ingram RG (1995) Experimental evidence of passive accumulation of marine bivalve larvae on filamentous epibenthic structures. Limnol Oceanogr 40: 94-104

Hills JM, Thomason JC (1996) A multi-scale analysis of settlement density and pattern dynamics of the barnacle Semibalanus balanoides. Mar Ecol Prog Ser 138:103-115

Jarret JN (1997) Temporal variation in substratum specificity of Semibalanus balanoides (Linnaeus) cyprids. J Exp Mar Biol Ecol 211:103-114

Keen SL (1987) Recruitment of Aurelia aurita (Cnidaria: Scyphozoa) larvae is position-dependent and independent of conspecific density within a settling surface. Mar Ecol Prog Ser 38:151-160

Keough MJ, Downes BJ (1982) Recruitment of marine invertebrates: the role of active larval choices and early mortality. Oecologia 54:348-352

Keough MJ, Raimondi PT (1995) Responses of settling invertebrates larvae to bioorganic films: effects of different types of films. J Exp Mar Biol Ecol 185:235-253

Knight-Jones EW (1953) Some further observations on gregariousness in marine larvae. Br J Anim Behav 1:81-82

Larman VN, Gabbott PA (1975) Settlement of cyprid larvae of Balanus balanoides and Elminius modestus induced by extracts of adult barnacles and other marine animals. J Mar Biol Assoc UK 55:183-190 
Le Tourneux F, Bourget E (1988) Implications of physical and biological settlement cues used at different spatial scales by the larvae of Semibalanus balanoides. Mar Biol 97 . $57-66$

Lemire M, Bourget E (1996) Substratum heterogeneity and complexity influence micro-habitat selection of Balanus sp. and Tubularia crocea larvae. Mar Ecol Prog Ser 135 $77-87$

Maki JS, Rittschof D, Schmidt AR, Snyder AG, Mitchell R (1989) Factors controlling attachment of bryozoan larvae: a comparison of filmed and unfilmed surfaces. Biol Bull 177:295-302

Meadows PS, Campbell JI (1972) Habitat selection by aquatic invertebrates. Adv Mar Biol 10:271-382

Mileikovsky SA (1974) On predation of pelagic larvae and early juveniles of marine bottom invertebrates by adult benthic invertebrates and their passing alive through their predators. Mar Biol 26:303-311

Minchinton TE, Scheibling RE (1993) Free space availability and larval substratum selection as determinants of barnacle population structure in a developing rocky intertidal community. Mar Ecol Prog Ser 95:233-244

Miron G, Bourget E, Archambault P (1996) Scale of observation and distribution of adult conspecifics: their influence in assessing passive and active settlement mechanisms in the barnacle Balanus crenatus (Brugière). J Exp Mar Biol Ecol 201:137-158

Morgan SG (1995) Life and death in the plankton: larval mortality and adaption. In: McEdwards I. (ed) Ecology of marine invertebrate larvae. CRC Press, Boca Raton, p $157-191$

Mullineaux LS, Garland ED (1993) Larval recruitment in response to manipulated field flows. Mar Biol 1 16:667-683

Mullineaux L.S, Butman CA (1991) Initial contact exploration and attachment of barnacle (Balanus amphitrite) cyprids settling in flow. Mar Biol 110:93-103

Neal AL, Yule AB (1994) The tenacity of Elminius modestus and Balanus perforatus cyprids to bacterial films grown under different shear regimes. J Mar Biol Assoc UK 74 : $251-257$

Nowell ARM, Jumars PA (1987) Flumes: theoretical and experimental considerations for simulation of benthic environments. Oceanogr Mar Biol Annu Rev 25:91-112

Pawlik JR, Butman CA (1993) Settlement of a marine tube worm as a function of current velocity: interaction effects of hydrodynamics and behavior. Limnol Oceanogr 38: $1730-1740$

Raimondi PT (1988a) Rock type affects settlement recruitment and zonation of the barnacle Chthamalus anisopoma (Pilsbury). J Exp Mar Biol Ecol 123:253-267

Raimondi PT (1988b) Settlement cues and determination of the vertical limit of an intertidal barnacle. Ecology 69 $400-407$

Raimondi PT (1990) Patterns, mechanisms and consequences of variation in settlement and recruitment of an intertidal barnacle. Ecol Monogr 60:283-309

Rittschof D, Branscomb ES, Costlow JD (1984) Settlement and behaviour in relation to flow and surface in larval barnacle Balanus amphitrite Darwin. J Exp Mar Biol Ecol 82:131-146

Editorial responsibility: Anthony Underwood

(Contributing Editor), Sydney, Australia
Rodriguez SR, Ojeda FP, Inestrosa NC (1993) Settlement of benthic marine invertebrates. Mar Ecol Prog Ser 97: 193-207

Snelgrove PVR, Butman CA, Grassle JP (1993) Hydrodynamic enhancement of larval settlement in the bivalve Mulinia lateralis (Say) and the polychaete Capitella sp. I in microdepositional environments. J Exp Mar Biol Ecol 168: 71-109

Sokal RR, Rohlf FJ (1995) Biometry. 3rd edn. WH Freeman, San Francisco

Sutherland JP (1990) Recruitment regulates demographic variation in a tropical intertidal barnacle. Ecology 71: 955-972

Todd CD, Keough MJ (1994) Larval settlement in hard substratum epifaunal assemblages: a manipulative field study of the effects of substratum filming and the presence of incumbents. J Exp Mar Biol Ecol 181:159-187

Turner EJ, Zimmer-Faust MA, Palmer MA, Luckenbach M, Pentcheff ND (1994) Settlement of oyster Crassostrea virginica larvae: effects of water flow and a water-soluble chemical cue. Limnol Oceanogr 39:1579-1593

Vogel $S$ (1994) Life in moving fluids, 2nd edn. revised and expanded. Princeton University Press, Princeton

Walters LJ (1992a) Field settlement locations on subtidal marine hard substrata: is active larval exploration involved? Limnol Oceanogr 37:1101-1107

Walters LJ (1992b) Post-settlement success of the arborescent bryozoan Bugula neritina (L.): the importance of structural complexity. J Exp Mar Biol Ecol 164:55-71

Walters LJ, Wethey DS (1991) Settlement refuges and adult body form in colonial marine invertebrates: a field experiment. Biol Bull 180:12-118

Walters LJ, Wethey DS (1996) Settlement and early post-settlement survival of sessile marine invertebrates on topographically complex surfaces: the importance of refuge dimensions and adult morphology. Mar Ecol Prog Ser 137: $161-171$

Walton Smith FG (1946) Effect of water currents upon the attachment and growth of barnacles. Biol Bull 90:51-70

Westernport Bay Environmental Study (1975) A preliminary report on the Westernport Bay environmental study: a report for the period 1973-74. Ministry of Conservation, Melbourne, Victoria

Wethey DS (1986) Ranking of settlement cues by barnacle larvae: influence of surface contour. Bull Mar Sci 39:393-400

Wieczorek SK, Todd CD (1997) Inhibition and facilitation of bryozoan and ascidian settlement by natural multi-species biofilms: effects of film age and the roles of active and passive larval attachment. Mar Biol 128:463-473

Wright JR (1996) Processes affecting the distribution and abundance of the barnacle Elminius covertus. PhD thesis, University of Melbourne

Yager PL, Nowell ARM, Jumars PA (1993) Enhanced deposition to pits: a local food source for benthos. J Mar Res 51 $209-236$

Young CM (1995) Behavior and locomotion during the dispersal phase of larval life. In McEdwards L (ed) Ecology of marine invertebrate larvae. CRC Press, Boca Raton, p 249-277

Submitted: June 2, 1998; Accepted: February 15, 1999 Proofs received from author(s): June 21, 1999 